\title{
Literature and Education in the Long 1930s
}

In Britain between the wars, and in the fiction of the period, education and its social and political effects were pressing questions. Contemporaries often agreed, as Ross McKibbin argues, that the 'most important' of education's functions was 'to encourage social mobility, to ameliorate social divisions, and to ... open $[$ education to all those who might benefit from it'. And yet from elementary education to university, the system observably worked to entrench class divisions, creating 'a fissure in social experience more fundamental than in any comparable country'. Of the generation born between 1910 and 1929, only 14.7 per cent of boys and 12.2 per cent of girls attended a secondary school of any kind, while only an elite 1.7 per cent went to university. ${ }^{1}$ Against the backdrop of this discrepancy between the commonly understood purpose of education and its actual effects, literature's entanglement with questions of education took many forms. Of course, as Anna Vaninskaya has argued, it would be reckless to generalise about the educational experiences of writers, since, 'as regards schooling ... the professional author was not part of any single recognized demographic'. ${ }^{2}$ Many of the period's most prominent writers were products of the public schools, and wrote about their experiences as pupils and teachers. From Evelyn Waugh's debut Decline and Fall (1928), through Graham Greene's edited collection of public school memoirs, The Old School (1934), to James Hilton's immensely popular Goodbye, Mr. Chips (1934), the public school was a fertile setting for both caustic satire and sentimental reminiscence. New kinds of educational institutions, including Board Schools (state-funded elementary schools), Socialist Sunday Schools, and the university extension movement, were also starting to make their presence felt in literature. Meanwhile, at the level of higher education, the 1930s are seen as a pivotal decade for the institutionalisation of English Literature as a university subject. Terry Eagleton wrote that 'In the early 1920s it was desperately unclear why English was worth studying at all; by the early 1930s it had become a question of why it was worth wasting your time on anything else'. ${ }^{3}$ Eagleton's account can be taken as representative of a wider tendency in the history of literary education in the 1930s, which has given a privileged place to F.R. Leavis's attempts to reform the Cambridge University English Faculty, and produced an episodic, short 1930s, characterised by sudden and fundamental changes enacted by a few men.

It would be impossible to give simultaneous consideration to all of the strands that link literature and education in the 1930s. This chapter hopes to establish, however, in keeping with this volume's emphasis on the 'long 1930s', that the period's ideas about literature and education need to be understood in a broader frame than the habitual focus on the elite contexts of Leavis's Cambridge, or the public school novel, have tended to provide. In doing so, it sets up a dialogue between contemporary literary historical accounts of the role of educational institutions, 
and (I suggest) fertile forms of institutional thinking that can be found in 1930s literature. Eagleton's Cambridge-centric account of the rise of English is accompanied by a suspicious reading of the social function of educational institutions which owes something to the thought of Louis Althusser. Cambridge English, in this reading, was at the centre of a system that promoted literary studies as a means of securing social and political stability: as Althusser put it, 'the school (but also other State institutions like the Church, or other apparatuses like the Army) teaches "know-how", but in forms which ensure subjection to the ruling ideology or the mastery of its "practice". 4

Literary-critical scepticism about institutions_-which has been marinating in the works of Foucault and Althusser for decades-has repeatedly confirmed its own prejudices by working with texts that seem to unmask the disciplinary structures that operate within and through institutions. Alexandra Lawrie has recently objected to Eagleton's picture of English Literature of a 'mode of social control' by refocussing our attention on the role of the extension movement. ${ }^{5} \mathrm{I}$ also want to look beyond Oxford and Cambridge as the locations of this debate, and I will focus here on schools. This chapter urges a rethinking of the relationship between literature, education and power, focusing on two writers who see in educational institutions genuine possibilities for social change: Winifred Holtby and Arthur Calder-Marshall.

\section{To Plan and Change Things by Deliberate Will}

Winifred Holtby's South Riding sets out to test a progressive educational agenda against the realities of provincial English life. The radical schoolmistress Sarah Burton-invested with ' $t$ ] he passion of all crusaders, missionaries and saviours'-is appointed as head of Kiplington Girls' High School in rural East Yorkshire. The entrenched institutional obstacles that confront her include, she reflects, 'A sticky board of governors. A moribund local authority. A dead end of nowhere.' Sarah's initial assessment of the educational possibilities of Kiplington Girls' High thus seems to offer a pessimistic account of the role of educational institutions in modern society. It emphasises both the 'stickiness' of the board of governors and the way in which the school prepares its students to take up pre-ordained positions within a capitalist order.

Yet for Holtby, schools and the institutions of local government that oversaw them were vital sites with the potential to enable social change from below. Her mother was an alderman in East Riding county council, and she dedicated South Riding to her, addressing her in a prefatory letter that reflected on 'the drama of English local government', remarking how 'apparently academic and impersonal resolutions passed in a county council were daily revolutionising the 
lives of those men and women they affected.' The ambitious task Holtby set herself in South Riding was to trace the 'complex tangle of motives prompting public decisions' and 'the unforeseen consequences of their enactment on private lives', which she saw as 'part of the unseen pattern of the English landscape'. ${ }^{6}$ Holtby titled each of the novel's eight books after a different branch of local government, and included as an epigram to each an extract from a fictional document from the relevant committee: minutes or a report, for example. Describing the novel to Vera Brittain, Holtby wrote that 'each part treats of some aspect of administration as it affects a human life_-or several human lives', which might lead us to imagine that the minutes and reports that form the epigram for each book are the diktats of a distant bureaucracy, imposed from the outside, whose effects are traced in the narrative. ${ }^{7}$ But the relationship between each book and its bureaucratic epigram is dialogic rather than deterministic. For example in Book 1, 'Education', the epigram is an 'Extract from the Minutes of the Higher Education Sub-Committee of the Education Committee established by the County Council for the South Riding of Yorkshire', in which Sarah Burton's appointment as head mistress of Kiplington High School is approved. ${ }^{8}$ In the body of the text itself is a description of Sarah's interview and the discussion which led to her appointment, in which a variety of views and interests are represented. As Holtby explained in her letter to Brittain, 'all the time a fight is going on between the people who want to plan and change things by deliberate will, and the people who just want to "let things happen". ' With this in mind, the epigrams are often revealed to have emerged out of the dramatic events described in the text itself, and are seen to express and embody the conflicting interests and aspirations of the residents of South Riding. Passivity in the face of institutional habits and norms is seen here as a moral choice, while the possibility that we might — if we strive to do so-change an institution 'by deliberate will' is open to us all. South Riding calls on readers to take some responsibility for the shape of the institutions they inhabit, and not simply to allow themselves to be formed by them. Holtby's work-both as a novelist and a journalist — radiates a confidence that the institutions, associations and organisations of civil society can successfully pursue ends that are both independent of governmental objectives and not reducible to the profit motive.

Holtby's educational ideas were profoundly shaped by this view of the immanent proximity and the transformative possibilities of the institutions of civil society. In South Riding, while Sarah is aware of the stickiness of the board of governors, she is confident in her ability to change the institution: 'I shall build up a great school here,' she thinks, 'I shall make the South Riding famous'. The confrontation between Sarah's lofty ambitions and the realities of the institutional landscape in which she will try to realise them is described in a chapter called 'Miss Burton 
Surveys a Battlefield', in which Holtby depicts Sarah as 'a commander inspecting a territory before planning a campaign'. ${ }^{10}$ These military metaphors call to mind Antonio Gramsci's roughly contemporaneous vision of the modern democratic state defended by 'a powerful system of fortresses and earthworks' made up of institutions, organisations and associations. Unlike Althusser-who rejected the very notion of civil society as a distinct sphere because he wanted to characterise all institutions as extensions of state power (Ideological State Apparatuses or ISAs) - Gramsci seemed to open the door to the possibility that institutions might be reformed and that such reform could be of strategic importance in what he termed a 'war of position'. This approach suited the 'massive structures of the modern democracies, both as State organisations, and as complexes of associations in civil society'. The left had little to gain under modern conditions, Gramsci argued, in attacking the political apparatus of the government in a 'war of manoeuvre', which he associated with Trotsky, 'the political theorist of frontal attack in a period in which it only leads to defeats.' ${ }^{11}$

Schools, in Gramsci's terms, form part of the extensive fortifications that protect the bourgeois state and ultimately the interests of the ruling class. But in a war of position, local skirmishes, within the institutions and associations that collectively constitute civil society, like the one in which Sarah finds herself embroiled, are worth fighting. In his fragment on education, Gramsci celebrates the traditional humanist education for its non-instrumental and disinterested pursuit of 'the interior development of personality, the formation of character by means of the absorption and assimilation of the whole cultural past of modern European civilisation'. The challenge for Gramsci was how to deliver this disinterested humanist education to the working class, with the aim of producing 'a new stratum of intellectuals, including those capable of the highest degree of specialisation, from a social group which has not traditionally developed the appropriate attitudes. ${ }^{12}$ Working class education, while not an end in itself, seems for Gramsci an essential front in the war of position as he understood it.

South Riding's reformism resonates with 1930s debates about working-class education, largely through its depiction of Lydia Holly, who lives in a railway coach in a cluster of makeshift dwellings known locally as 'The Shacks'. 'It was for such as her', Holtby's narrator reports, 'that the Kiplington High School of Sarah's dreams should be constructed'. Lydia is awakened to the educational possibilities of literature when she reads Shakespeare, lent to her by another resident of The Shacks with the advice: 'Better try to improve your mind. Read something worthwhile. Culture-not just this trash. Read Shakespeare'. Reading the imperial votaress speech from $A$ Midsummer Night's Dream, Lydia dreams of a literary education: she has won a scholarship to the High School, where she hopes 'to learn French and Science, to play hockey, to have a desk and 
locker, and to read books and books and books, unreprimanded, because it was her business'. ${ }^{13}$ She is interested, not simply in being trained for a job, but in something closer to that 'formation of character' afforded by humanist education.

\section{The Ethos of the Hearth}

Advocates of working-class education often wondered whether the educated poor would absorb bourgeois mores and become cut off from working class culture and political associations. The National Council of Labour Colleges (N.C.L.C.) was established to ensure that this did not happen, advocating an 'independent working-class education' in order to 'win the workers, one by one, from the intellectual camp of capitalism'. The president of the N.C.L.C., W.A. Strawbridge, argued that 'the educational system turns out the child as a fit and serviceable instrument of capitalism' and that 'the capitalist press, cinema, sport, the W.E.A., as the instrument of the Universities, the B.B.C. and religious organisations do the rest in riveting the chains of mental and moral slavery on him'. ${ }^{14}$ J.P.M. Millar, General Secretary of the N.C.L.C., referred to these latter as parts of the 'State educational machinery', strikingly pre-empting the language of Althusser. The N.C.L.C. 'confine[d] itself to running classes, etc., on subjects of direct importance to the work of the Trade Union, Labour, and Co-operative movements.' ${ }^{15} \mathrm{~A}$ Marxist and proletarian curriculum was set out, emphasising politics and economics. ${ }^{16}$ Literature, which the N.C.L.C. considered essentially bourgeois, played at best a peripheral role: in a 1939 list of the thirty-four main subjects covered by the organisation, only 'Literature and Social Conditions' included literature, and even that suggested a social-scientific version of the discipline. ${ }^{17}$ The N.C.L.C. saw itself as a counter-institution responsible for sustaining a workingclass education that was entirely independent from bourgeois culture.

The fear that a humanist education might alienate the working class from their culture and even their families was memorably articulated after the war by Richard Hoggart in The Uses of Literacy (1957). Hoggart described the means by which the working class 'scholarship boy' is 'progressively cut off from the ordinary life of his group', and 'will have, probably unconsciously, to oppose the ethos of the hearth'. ${ }^{18}$ While Hoggart found in this severance an occasion for melancholy, in South Riding, Lydia initially takes great pleasure in the possibility that education may provide her with a means of escaping from her dreary surroundings: her Shakespearean reverie allows her to tune out 'her mother's weary voice, scolding Gertie for letting Lennie, the latest baby, cut his lip on a discarded salmon tin'. Lydia's working class family constantly threatens to hold her back, as when her mother dies and she is forced to take on more domestic responsibilities: for some time it looks as if she will have to leave the High School entirely (until 
Sarah intervenes to ensure that Lydia can continue her education). Yet the school itself is not insulated from working-class culture. Visiting the school prior to taking up her post, Sarah is shocked to find the students engaging in 'so vivid an imitation of music hall naughtiness' and a dance 'as frankly indecent as anything that Sarah had seen on an English stage'. Lydia, who had wanted 'to read books and books and books', is now seen 'to romp with noisy and cheerful athleticism through a Dutch Doll Dance'. The High School provides a less erudite literary education than did the autodidact who first put Shakespeare into Lydia's hands. ${ }^{19}$

There has been a tendency to read the novel as if Sarah's social attitudes were identical with Holtby's, but it seems to me that this negative view of music hall, and workingclass culture in general, is part of Holtby's satirical portrayal of Sarah. ${ }^{20}$ In fact, Holtby celebrated music hall culture in an unpublished but passionately argued article on music hall, insisting that 'there is a quite permanent and rational value about a vulgar song'. ${ }^{21}$ This might prompt us to pay more attention to the ways in which South Riding also asks the reader to consider Sarah's project of ‘turning giggling little girls into young women' from a workingclass perspective. Mr. Holly, Lydia's perennially unemployed and constantly drunk father, is proud that his daughter ' $[\mathrm{f}]$ rames to be a real scholard'. But when he takes tea with Sarah the question of class overrides the earnest discussion of Lydia's education. Mr. Holly later praises Sarah for 'drinking tea out of a thimble' and 'passing me cake cut in bits no bigger than a tit's arse-hole'. ${ }^{22}$ The satirical implication is that Sarah's ambitions for the girls are all about getting them to take tea and cake in appropriately dainty quantities.

\section{An Expanding Elite?}

For certain critics who developed Leavis's ideas in the postwar period, the class-bound status of a literary education did not negate the effort to expand it. C.B. Cox and A.E. Dyson, for example, established the Critical Quarterly in 1958 to carry on the task of Leavis's Scrutiny in defending the value of past traditions, but they opposed what they saw as the cultural pessimism— 'the 'waste land' mentality' —of the Scrutineers. '[W] committed ourselves optimistically to faith in the possibility of an expanding elite', they wrote, noting that 'The Critical Quarterly discovered an audience among intelligent readers outside the university, particularly in the schools. ${ }^{23}$ The desire to extend Cambridge English through an expanding network of schools and other institutions fitted the Eagleton model of post-Leavisite English Literature as a sort of Althusserian ISA mixed with a finishing school. It sought to separate the educated poor from working-class culture and political associations in order to welcome them into an expanded middle class. 
Holtby herself pioneered her own attempt to expand the elite, seeking to disseminate the fruits of her Oxford education to the schools in her weekly column for The Schoolmistress. The columns sometimes provided knowledgeable digests that Holtby's schoolmistress readers might use in the classroom, as in 'Farms in Fiction', 'The Russians', and 'John Galsworthy, OM'. ${ }^{24}$ Yet Holtby constantly emphasised the question of how education might be transformed from below. In her impressionistic account of the National Union of Teachers conference in 1933, Holtby sat bored through a speech by 'Bede, the teacher monk', who implied that 'beyond the little lighted chambers of learning and piety and memory of the sacred past lay barbarism and cruelty and men's untutored greed'. ${ }^{25}$ It was a vision of an embattled elite which it was the task of conservative educationalists to protect, and progressive ones to extend. Holtby was suspicious of the pronouncements from the stage, and more interested in the conversations taking place on the floor, including complaints about the policy that excluded married women from the profession. ${ }^{26}$ She drifted into a reverie about the history of working class education, understood not as the expansion of a priestly caste, but as a growth from below, seeing (among others), 'a hedge-schoolmaster gather his pupils around him', while a 'loutish farm labourer thumbed a battered horn-book', and imagining 'a lady, neat, pious, trim, setting off with a basket of eggs, a Bible, and spelling book, to teach the poor of her village'. ${ }^{27}$ This polycentric account of workingclass education deliberately excluded the diffusionist model of an expanding elite, in favour of a somewhat chaotic carnival that sprang from autodidactic culture itself.

Holtby feared that the teaching profession tended to 'draw its members into a narrowing circle' and by way of remedy she proposed a system of sabbaticals enabling an inward-looking and cloistered elite to experience other walks of life. She even suggested—with a characteristically light touch-that 'an overconscientious mistress in a girls' boarding school, who leads a nun-like existence growing more and more remote each year from a workaday world and its vulgarities, would really enjoy being a barmaid at a big London music-hall once she got over the shock of it. ${ }^{28}$ Holtby's notion that teachers needed not merely to disseminate their Oxford education to the masses, but also to learn dialogically from those they purported to teach, was part of her wider approach to institutional change from below. In an article for the Yorkshire Post, Holtby looked at the reforming role played by institutions and committees. 'And for the rest of us, not the Uplifters but the Uplifted?', she asked, 'How do we survive the efforts of those who would improve us?' But she rapidly changed direction: 'On the whole, we seem to bear up pretty well, perhaps because-as in the Producer-Consumer controversy-most of us are a bit of both.' Institutional forms, for Holtby, are not imposed on us from the outside, but spring out of, and have the potential to nurture, specific individual aims and projects. We are 
simultaneously Uplifters and Uplifted, agents and objects of institutional reform. Holtby suggested, moreover, that the stickiness of institutions might not be straightforwardly conservative, but could become the means by which social change stands a chance to outlive the individual who seeks to enact it:

For man the individual there is no lasting happiness, no sure fulfilment. But the enthusiast who has projected a freedom of his personality onto an impersonal cause, a movement, a committee, has laid hold upon imperishable stuff, though with uncertain fingers. He has delegated to some extent his hopes and fears and passions. He passes, but the educational reforms, the babies' hospitals, the sugar beet industries, or preserved old buildings remain. And if his cause fails, or if he dies like Moses before reaching the promised land, he at least believes that some day, somewhere, someone else will reach it. $^{29}$

Imperishability is what makes the effort of trying to reform institutions worthwhile: social change is likely to stick when it takes an institutional form. As Gramsci's theory of the 'war of position' implied, institutions are an important means by which the individual personality might make some sort of impression on history.

Holtby's attempt to disturb the hierarchy between 'Uplifters' and 'Uplifted' implies a different attitude to students than we find in advocates of the 'expanding elite'. Over the course of South Riding, Sarah's approach to teaching changes as she seeks increasingly to empower her students as critics of institutional authority. Towards the end of the novel, in a discussion of the hymn 'I vow to thee, my country' (and in particular the phrase that praises patriotism as 'The love that asks no questions') Sarah advises: 'Question everything-even what I'm saying now. Especially, perhaps, what I say.' Part of that new openness to questioning might allow for Sarah's own class-bound habits, not least eating 'cake cut in bits no bigger than a tit's arse-hole', to be subject to a defamiliarising view from below. ${ }^{30}$ Sarah moves, at the end of the novel, to amplify the voices of her pupils. These voices might form the basis of a kind of counter-institution, but — unlike the paradoxical anti-insitutionality of the N.C.L.C.—one that is understood to originate and take effect within the existing structure itself.

In an article on 'Youth and its Rituals', Holtby explored the norms which students themselves institutionalised. She invoked anthropology as a means of understanding the 'Unwritten Law', the set of rigorously enforced school conventions that are not imposed from above but originate within the student body itself: 'Thank heaven, to-day we have the 
anthropologists explaining to us that primitive peoples are bound about by a network of conventions.' Describing her own first arrival at school, she recalled that 'life seemed to me as it might do if I suddenly woke up today in one of the more primitive societies described in Frazer's "Golden Bough."”31 Holtby was determined to pay close attention to the social structures she found in the school, and to learn from them.

\section{Calder-Marshall's Anthropology of the Public School}

Arthur Calder-Marshall was, like Holtby, an Oxford-educated left-winger who became a teacher and a writer, though unlike her he was for a while a Communist, and his teaching experience was in public schools rather than local authority ones. Yet his approach to understanding of educational institutions bears comparison with Holtby's. He also invokes anthropology as a corrective to an educational approach he identifies as monastic. In his pamphlet Challenge to Schools, he finds in the public school system 'a state of society analogous to those found in savage communities' that begs to be studied by 'a psychological anthropologist like Theodore Reik' rather than 'an academic educationalist.' Calder-Marshall focusses on the institutionalisation of homosexuality and of 'foolish customs' such as speech taboos, flogging and fagging. In the case of flogging, Calder-Marshall acknowledged that the practice is sadistic, but nevertheless retorted that 'The public schools, because they legitimise and admit the existence of this sadism, are acting more wisely than those who think they can annihilate sadism by denying its outlet.' Calder-Marshall's own attempts, as a schoolmaster, to criticise fagging were dismissed by schoolboys, 'the most resolute guardians of the system' which 'was evolved by them; and [...] persists because of their sponsorship, not because of that of masters'. The system of customs and taboos, developed and defended by the student body, 'provides within its frame means of extraordinary diversity for boys to express and work through their predominant needs. ${ }^{32}$

In his public school novel, Dead Centre (1935), Calder-Marshall used an ostentatiously polylogic structure to bring the various personal and educational dilemmas of the teaching staff into dialogue with those of the boys and the other employees of Richbury School. ${ }^{33}$ Each chapter is written from the first person perspective of a different pupil, teacher, or other employee of the school. This determination to pay attention to the autochthonic culture of the boys, and to understand them as actively involved in shaping the school as an institution, was part of a wider project to destabilize the hierarchy of the 'Uplifters' and the 'Uplifted' as Holtby put it. In particular it was juxtaposed with a top-down model of education that sought to inculcate rulingclass values: ' $[\mathrm{t}]$ he fundamental attitude of the public schools is capitalistic and conservative', he wrote. They effectively produced 'a large class of men, who have not reached full growth, whose 
sensibilities are blunted $[\ldots]$ domesticated like doped lions in a circus ring or performing seals.' Calder-Marshall's analysis is inimical to the ideal of the 'expanding elite'. He recognised the process by which Oxford and Cambridge educate teachers who then spread the values of those institutions into the ruling class. But he saw these as 'monastic, or homosexual institutions': 'These two universities especially are cut off from the world. Their values are values prevailing nowhere else. Repression, snobbery and fantastic idealism flourish there. The atmosphere of immaturity is rank. ${ }^{34}$ Some might feel that the possibility that the public schools may communicate some features of the Oxbridge education to their students is a redeeming feature to set against the damaging effects of flogging, fagging and schoolyard taboos. Calder-Marshall argued, conversely, that flogging itself was one of the key compensations of a public school education, in contrast with the detrimental influence of social attitudes fostered in the monastic atmosphere of Oxford and Cambridge.

\section{$\underline{\text { Literature and Mental Freedom }}$}

For Calder-Marshall, literature played a potentially important role in destabilising educational hierarchies, and the polyphonic structure of Dead Centre encouraged readers to explore its significance from the perspective of teachers, pupils and janitors. In the chapter narrated by Green (aged 14), we learn that 'Piddles' (as Green calls him) singles him out for special and 'unfair' treatment, setting him to copy out five hundred lines of Milton's Paradise Lost, which Green declares 'awful muck'. In Biddles's chapter, we discover that Green is a particular favourite of his, whose 'qualities of character and independence' he admires. The use of Paradise Lost as a punitive device is part of the failed educational approach that is associated in Dead Centre with the headmaster, who coins the epigram 'man cannot follow two masters, and the sole master in a public school is the Headmaster'. ${ }^{35}$ In Challenge to Schools, Calder-Marshall lambasted a 'censorship' that had taken hold in the public school curriculum, and that is not merely political' but 'sexual, religious, moral and aesthetic'. Calder-Marshall encouraged boys to read beyond the canon, opening his library to lend them 'Lawrence, Faulkner, Hemingway, Tully, Huxley, Graves, Sassoon, Eliot, Campbell, Auden and Spender'. This had the effect that the students 'became critical, able to distinguish between good and bad writing, false and true emotions. They began to discuss, dissent and have enthusiasms.' They experienced 'mental freedom'. ${ }^{36}$

It is in places such as this where a positive educational programme starts to emerge from Challenge to Schools. Calder-Marshall was highly suspicious of 'progressive education', wherein the 'evil tendencies' of boys are 'denied as strenuously as were formerly their good ones'. Moreover, although he was a Communist he did not 'sympathize with political education in any partisan 
sense', suggesting for example that the works of Lenin and Trotsky ought to be taught in dialogue with bourgeois political theorists:

I believe that Communism is the only solution of the problems before us. But when I was a schoolmaster I considered it an essential part of my job to argue and present capitalist and socialist positions also. [...] I carried this impartiality to such a length that my pupils were upset. They demanded to know what I thought; until I pointed out that I was not there for that purpose, but to find out what they thought. ${ }^{37}$

Calder-Marshall's notion that 'the schoolmaster's duty is to ... present not one, but every side of a question' is embodied in the polyvocal form of Dead Centre, which models an ideal educational experience, even while the educational experiences described in it are typically frustrating and alienating. Calder-Marshall sees a direct link between literature's capacity to educate readers in different points of view, and the institutional transformation of the school: 'In this mental liberation, the sexual tensions which issue in flogging and bullying will be sublimated towards knowledge. A boy will attack a problem rather than Jones Minor, and flagellate falsehood instead of his fag, ${ }^{38}$ As in Holtby, the hope is that the rituals and the culture of the pupils could coalesce into some kind of counter-institutional, counter-hegemonic formation within the public school, rather than outside or against it.

Calder-Marshall's arguments about the transformation of the public school must be seen in the context of his commitment to Communism. He was sceptical of the public schools' limited attempts to educate the working class, labelling the scholarship system 'an excellent device for rendering them harmless' that 'utilizes unconscious herd instinct and produces a feeling of gratitude in the very class whose corporate union it is its purpose and effect to destroy'. Contemplating a brighter future, with Britain transformed by 'revolution or tranquil development', Calder-Marshall looked forward to the time when 'the public schools ... will be incorporated into a system of State education, the purpose of which will be to equip citizens who will work in the interests of the world as a whole. ${ }^{39}$ The public schools survived the Labour landslide of 1945, and Attlee's failure to capitalise on a clear opportunity to abolish or reform them must count as among the most significant failures of his transformative government. ${ }^{40}$ While Attlee's government pursued an agenda of nationalising major industries such as steel and coal, many of the institutions of civil society (Gramsci's 'educative state') remained immune from reform. The Attlee government underestimated the 'stickiness' of educational institutions and it 
ceded ground in the war of position in which Holtby and Calder-Marshall understood themselves to be engaged.

Both Calder-Marshall and Holtby—from very different positions on the left—interrogate the idea that schools are purely hegemonic institutions controlled by the ruling class. Instead, they bring to bear an institutional anthropology of the school that explores the possibilities of change from below. Autochthonic culture-whether characterised by fagging (in CalderMarshall) or music hall (in Holtby) — was not the new educational content to replace classical learning: Calder-Marshall's proposals for the curriculum and his critique of the boys' 'barbarian ... rituals' sought to correct a conservative bias, but (unlike the hardliners of the N.C.L.C.) he did not advocate a proletarian reading list. Both the 'composite method' of Dead Centre and the deployment of county council minutes in South Riding are formal devices that seek to demonstrate the active participation of multiple people in creating a direction for the institution. In Calder-Marshall's and Holtby's hands, the educational institution itself becomes a crucial site for social and cultural change, whether (for Calder-Marshall) as a vital component of a political revolution or (for Holtby) as part of a progressive, liberal educational agenda that was open to classical humanism, but not restricted by the values of a monastic elite.

${ }^{1}$ R. McKibbin, Classes and Cultures: England 1918-1951 (Oxford: Oxford University Press), pp. 259, 269, 260, 248

2 A. Vaninskaya, “It was a silly system": writers and schools, 1879-1939', The Modern Language Review, 105.4 (2010), 952-75 (956, 953)

${ }^{3}$ T. Eagleton, Literary Theory: An Introduction, second edn. (Oxford: Blackwell, 1996), p. 27

${ }^{4}$ L. Althusser, 'Ideology and ideological state apparatuses' in B. Brewster (trans.), Lenin and Philosophy and Other Essays (New York, NY: Monthly Review Press, 2001), pp. 127-86 (p. 133)

${ }^{5}$ A. Lawrie, The Beginnings of University English: Extramural Study, 1885-1910 (Basingstoke: Palgrave, 2014), pp. 5,1

${ }^{6}$ W. Holtby, South Riding (London: Fontana, 1974) p. 5

${ }^{7}$ Holtby qtd. in V. Brittain, Testament of Friendship: The Story of Winifred Holtby (London: Virago Press, 1980), p. 416

${ }^{8}$ Holtby, South Riding, p. 29

${ }^{9}$ Holtby qtd. in Brittain, Testament of Friendship, p. 416

${ }^{10}$ Holtby, South Riding, pp. 66-7

11 A. Gramsci, Selections from the Prison Notebooks, ed. and trans. Q. Hoare and G. N. Smith (London: Lawrence and Wishart, 1971), pp. 238-39, 243

12 Gramsci, Prison Notebooks, pp. 37, 43. My reading of Gramsci is no doubt guilty of the 'illusions of left social democracy' that P. Anderson diagnosed in a key article from 1976, 'The antimonies of Antonio

Gramsci', New Left Review, 1.100 (1976), pp. 5-78 (p. 27).

${ }_{13}$ Holtby, South Riding, pp. 129, 50-1

${ }^{14}$ W. A. Strawbridge, Education and the World Crisis: Being the Presidential Address of W. A. Strawbridge to the Tenth Annual Meeting of the National Council of Labour Colleges (London: National Council of Labour Colleges, 1931), pp.11-12

15 J. P. M. Millar, Thirty Years of Independent Working Class Education (London: National Council of Labour Colleges, 1939), pp. 3, 6 
${ }^{16}$ The relationship between the N.C.L.C.'s 'independent working-class education' and the liberal pluralism of the W.E.A. is explored in J. Rose, The Intellectual Life of the British Working Classes (New Haven: Yale Nota Bene, 2002), pp. 256-97

${ }^{17}$ Millar, Thirty Years of Independent Working Class Education, p. 7

${ }^{18}$ R. Hoggart, The Uses of Literacy: Aspects of Working Class Life (London: Penguin, 2009), p. 265

${ }^{19}$ Holtby, South Riding, pp. 50, 84, 86, 88

20 The assumption that Sarah's social attitudes are identical with Holtby's is made in H. Julien, 'School novels, women's work, and maternal vocationalism', NWS A Journal, 19.2 (2007), 118-37

${ }^{21}$ W. Holtby, 'In defence of music halls', typescript article, Winifred Holtby Collection, Hull History Centre, L WH/1/1.12/01p

${ }^{22}$ Holtby, South Riding, pp. 178, 167, 351

${ }^{23}$ C. B. Cox and A. E. Dyson, 'Literary criticism' in C. B. Cox and A. E. Dyson (eds.), The TwentiethCentury Mind: History, Ideas, and Literature in Britain, 3 vols. (Oxford: Oxford University Press, 1972), vol. III, pp. 440-63

${ }^{24}$ W. Holtby, 'The Russians', The Schoolmistress, 103.2677 (1933), (713, 733); 'John Galsworthy, OM', The Schoolmistress, 103.2670 (1933), n.p.; 'Farms in fiction', The Schoolmistress, 103.2668 (1933), n.p.

${ }^{25}$ W. Holtby, 'On the N.U.T. Conference', The Schoolmistress, 104.2681 (1933), pp.77, 103

${ }^{26}$ Holtby protested that policy elsewhere, for example in an undated letter in response to an article on an 'Education policy for progressives' by Percy Harris, where Holtby wrote of 'the most illiberal policy of dismissing upon marriage, or refusing to appoint after marriage, women teachers', citing the 'unwarrantable interference in personal liberty' and also a 'flagrant ... act of false economy'. Winifred Holtby Collection, Hull History Centre, L WH/2/2 27/01b

${ }^{27}$ Holtby, 'On the N.U.T. Conference', 103

${ }^{28}$ W. Holtby, 'Desperate remedies: how to cure the teaching profession', The Manchester Guardian, 17th Feb. 1931,6

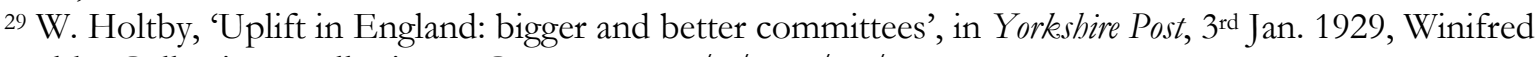
Holtby Collection, Hull History Centre, L WH/2/2.26/03/01a

${ }^{30}$ Holtby, South Riding, pp. 506, 351

${ }^{31}$ W. Holtby, 'The age of convention: youth and its rituals', Yorkshire Post, 12 $2^{\text {th }}$ Jan. 1929

32 A. Calder-Marshall, Challenge to Schools: A Pamphlet on Public School Education (London: Hogarth Press, 1935), pp. 25, 27, 28

33 P. Baker, 'Marshall, Arthur Calder- (1908-1992)', in Oxford Dictionary of National Biography (Oxford

University Press, 2004), www.oxforddnb.com/view/article/50937

${ }^{34}$ Calder-Marshall, Challenge to Schools, pp. 28, 12-13, 19

35 A. Calder-Marshall, Dead Centre (London: Cape, 1935) pp. 27, 221

${ }^{36}$ Calder-Marshall, Challenge to Schools, pp. 30-1

${ }^{37}$ Calder-Marshall, Challenge to Schools, pp. 31, 29

${ }^{38}$ Calder-Marshall, Challenge to Schools, p. 32

${ }^{39}$ Calder-Marshall, Challenge to Schools, pp. 42-3

${ }^{40}$ R. McKibbin, Parties and People: England, 1914-1951 (Oxford: Oxford University Press, 2010), p. 161 